\title{
Filmforming Antitranspirants: Their Effects on Root Growth Capacity, Storability, Moisture Stress Avoidance, and Field Performance of Containerized Conifer Seedlings
}

\author{
by
}

\author{
David G. Simpson ${ }^{1}$
}

\begin{abstract}
The antitranspirants, XEF-4-3561-A, Wilt Pruf, Plantgard, Folicote, Clear Spray, and Vapor Gard, were sprayed on container-grown lodgepole pine, white spruce, western hemlock, and Douglas-fir seedlings before or after a 12 -week cold $\left(+2^{\circ} \mathrm{C}\right)$ storage period. The effects of the six antitranspirants on root growth capacity, storability, and field performance varied between species. XEF-4-3561-A, Wilt Pruf, Folicote, and Vapor Gard increased moisture stress avoidance of all species, while Plantgard and Clear Spray had no effect. None of the six antitranspirants are recommended for use on white spruce, western hemlock, or Douglas-fir planting stock because of the risk of reducing field performance. Further trials of XEF-4-3561-A and Wilt Pruf on lodgepole pine seedlings seem warranted.
\end{abstract}

\section{Résumé}

Les antitranspirants XEF-4-3561-A, Wilt Pruf, Plantgard, Folicote, Clear Spray et Vapor Gard ont été pulvérisés sur des plants cultivés et récipients de pin tordu, d'épinette blanche, de pruche occidentale et de douglas taxifolié avant ou après une période de conservation au froid $\left(+2^{\circ} \mathrm{C}\right)$ de 12 semaines. Les effets des six antitranspirants sur la capacité d'accroissement des racines, la capacité de conservation et la performance sur le terrain ont varié selon les espèces. XEF-4-3561-A, Wilt Pruf, Folicote et Vapor Gard ont accru la résistance au stress hydrique chez toutes les espèces, mais Plantgard et Clear Spray ont été sans effet. Aucun des six antitranspirants n'est à recommander sur les plants d'épinette blanche, de pruche occidentale et de douglas taxifolié en raison du risque de diminution de la performance sur le terrain. D'autres essais de XEF-43561-A et de Wilt Pruf sur des plants de pin tordu paraissent justifiés.

\section{Introduction}

Loss of water by conifer seedlings, either in cold storage or after field planting, may result in growth-limiting or even lethal levels of plant moisture stress. During overwinter cold or frozen storage, seedling water loss is usually minimized by packaging the seedlings in cartons or bags with polyethylene or wax vapor barriers. Once planted on a forest site, water loss must be controlled by stomatal action. Frequently, seedlings are planted in environments that are conducive to foliage water loss, but at the same time, restrict water uptake. The net result is to subject the planted seedlings to growth- and survival-limiting levels of internal plant moisture stress.

Filmforming antitranspirants have been used on herbaceous plants (Anderson and Kreith 1978, Martin and Link 1978, McDaniel and Bresenham 1978), on deciduous fruit trees (Albrigo 1977, Weller and Ferree 1978), and also on forest tree species (Davies and Kozlowski 1974, 1975). This literature suggests that available products have varying effects on transpiration and may reduce photosynthesis or possibly cause mortality. A screening process is, therefore, necessary before filmforming antitranspirants should be considered for use on conifer planting stock.

\footnotetext{
${ }^{1}$ Research Biologist, Kalamalka Research Station \& Seed Orchard, BC Ministry
} of Forests, Vernon, BC. V1B 2 C7
This paper reports effects of six filmforming antitranspirants on root growth capacity, storability, moisture stress avoidance, and field performance; and assesses their suitability for use on lodgepole pine (Pinus contorta Doug.), white spruce (Picea glauca (Moench) Voss), western hemlock (Tsuga heterophylla (Raf). Sarg.), and Douglas-fir (Pseudotsuga menziesii (Mirb.) Franco) planting stock.

\section{Materials and Methods}

In February 1981, 11200 container-grown lodgepole pine, white spruce, western hemlock, and Douglas-fir seedlings from British Columbia Ministry of Forests nurseries were removed from cold $\left(0^{\circ}\right.$ to $\left.2^{\circ} \mathrm{C}\right)$ storage. Seedlings of each species were randomly divided into 56 lots of 50 trees each, to provide four replicates of 14 treatments.

Six commercially available filmforming antitranspirants were applied in aqueous solution to the seedlings' foliage using a low pressure sprayer (Table 1). The antitranspirant sprays were applied to the lots of 50 seedlings such that all the shoots were well-coated. Two operationally feasible application times were evaluated. Treatment before, or during, winter cold storage was represented by seedlings returned to storage for 12 weeks after treatment. Treatment shortly before planting was represented by seedlings treated at the end of 
storage and stored seven days or less between treatment and planting. An untreated control was provided for each group to maintain a balanced experiment, and minimize possible differences in mid-storage warming effects on post-storage physiology and field performance. The antitranspirant treatment of seedlings required that seedlings were removed from cold storage for no more than 6 hours and not subject to air temperatures exceeding approximately $15^{\circ} \mathrm{C}$.

\begin{tabular}{|c|c|c|c|}
\hline & $\begin{array}{l}\text { Product } \\
\text { dilution }\end{array}$ & $\begin{array}{l}\text { Type of } \\
\text { compound }\end{array}$ & Supplier \\
\hline XEF-4-3561-A & $1: 10$ & $\begin{array}{l}\text { Silicone } \\
\text { emulsion }\end{array}$ & $\begin{array}{l}\text { Dow Corning Corp. } \\
\text { Midland, Mich. } \\
48640\end{array}$ \\
\hline Wilt Pruf & $1: 10$ & Pinolene & $\begin{array}{l}\text { Nursery Specialty } \\
\text { Products } \\
\text { Greenwich, CT } \\
06830\end{array}$ \\
\hline Plantgard & $1: 5$ & $\begin{array}{l}\text { Polyethylene } \\
\text { emulsion }\end{array}$ & $\begin{array}{l}\text { Polymetrics Inter- } \\
\text { national Inc. } \\
\text { New York, NY } \\
10022\end{array}$ \\
\hline Folicote & $1: 20$ & Wax emulsion & $\begin{array}{l}\text { Crystal Soap and } \\
\text { Chemical Corp. } \\
\text { Lansdale, PA } \\
19446\end{array}$ \\
\hline Clear Spray & $1: 10$ & $\begin{array}{l}\text { Acrylic } \\
\text { polymer }\end{array}$ & $\begin{array}{l}\text { W.A. Cleary Corp. } \\
\text { Somerset, NJ } \\
08873\end{array}$ \\
\hline Vapor Gard & $1: 20$ & Pinolene & $\begin{array}{l}\text { Miller Chemical and } \\
\text { Fertilizer Corp. } \\
\text { Hammer, PA } \\
17331\end{array}$ \\
\hline
\end{tabular}

A 7-day root growth capacity (RGC) test (Burdett 1979), commonly used for operational testing in British Columbia nurseries, was conducted on 16 randomly selected seedlings from each antitranspirant treatment applied before the 12week storage period. The RGC test was conducted by growing the seedlings potted in an unfertilized $\mathrm{pH} 5.5$ peat: vermiculite soil medium in controlled environment chambers (Conviron E15, Conviron Systems Co., Winnipeg, Manitoba) providing the following conditions: $30^{\circ} \mathrm{C}$ day and $25^{\circ} \mathrm{C}$ night temperature; 16 -hour daily photoperiod $\left(400 \mu \mathrm{E} \mathrm{m}^{-2} \mathrm{~S}^{-1}\right) ; 75 \%$ relative humidity. After 7 days, the seedlings were scored for the number of roots elongated during the test as follows: $0=$ no newly elongated roots; 1 = some newly elongated roots, none more than $10 \mathrm{~mm} ; 2=1$ to 3 roots elongated by more than $10 \mathrm{~mm} ; 3=4$ to 10 roots elongated by more than $10 \mathrm{~mm} ; 4=11$ to 30 roots elongated by more than $10 \mathrm{~mm} ; 5=31$ to 100 roots elongated by more than $10 \mathrm{~mm}$. Testing occurred immediately after treatment (pre-storage RGC), and after the 12-week cold storage period (post-storage RGC). A storability rating was calculated from the pre- and post-storage measurements.

$$
\text { Storability }=\frac{\text { post-storage RGC of treatment " } x \text { " }}{\text { pre-storage RGC of untreated seedlings }}
$$

Storability values equal to, or greater than 1.0, suggest that seedling quality, or performance potential has been maintained or increased during cold storage. Conversely, storability values less than 1.0 suggest that seedling quality has diminished during cold storage.

Water potential measurements, using the pressure chamber method (Waring and Cleary 1967), were made on shoots of 16 seedlings per antitranspirant treatment after the 7-day RGC test. Measurements were made within two minutes of removal from the dark period, $25^{\circ} \mathrm{C}, 75 \% \mathrm{RH}, \mathrm{RGC}$ test environment.

A moisture stress avoidance test, involving measurement of pre-dawn water potential, was conducted on the white spruce seedlings in a warm glasshouse between July 3 and 22, 1981. In this test, seedlings were planted in coarse sand, well watered for 7 days, then not watered. Ten pre-dawn water potential measurements were made at appropriate (1 - to 3 day) intervals until water potential levels reached $-6.0 \mathrm{MPa}$ $(-60$ bars) or the seedlings were dead. To minimize the effects of uneven soil water depletion, seedlings were planted into 40 sand-filled compartments $12 \mathrm{~cm}(\mathrm{D}) \times 6 \mathrm{~cm}(\mathrm{~W}) \times 50 \mathrm{~cm}$ (L). Each compartment contained one randomly planted and evenly spaced seedling from each treatment, plus two extra seedlings at the ends of each compartment to reduce edge effects on soil water competition between seedlings. On each of the 10 measurement dates during the drought period, four compartments were selected randomly, and pre-dawn water potential measurements made on the seven treated seedlings in each of those compartments.

The influence of antitranspirants and application time on field performance was evaluated as first growing season survival and growth by outplanting the remaining seedlings at two sites. Lodgepole pine and white spruce seedlings were planted near Prince George, BC as 20 -seedling row plots in a randomized complete block design with four blocks. Western hemlock and Douglas-fir were planted in a similar randomized complete block design in the transplant beds of BC Ministry of Forests' Surrey Nursery near Vancouver, BC. The Prince George and Surrey nursery plantings occurred on May 12 and April 10,1981, respectively. First season survival and shoot growth were assessed in late September, 1981 at both sites.

Pre- and post-storage RGC, water potential, field survival, and growth data were subjected to analysis of variance. Treatment effects were tested for significance using the Student Newman-Keuls test (Zar 1974). Water potential differences between specific treatment and untreated samples on each sample date of the moisture stress avoidance test were tested for significance using the Student's t-test.

\section{Results and Discussion}

Both pre- and post-storage root growth capacity of white spruce and western hemlock seedlings were unaffected by the six antitranspirant treatments (Table 2). There were slight, but statistically significant reductions of both pre- and poststorage RGC for lodgepole pine seedlings treated with Folicote and Vapor Gard. Douglas-fir seedlings treated with XEF4-3561-A showed significant reductions in pre- and post-storage RGC, but only post-storage RGC of Douglas-fir seedlings was adversely affected by Wilt Pruf and Vapor Gard.

Storability was adversely affected by Folicote and Vapor Gard in lodgepole pine; XEF-4-3561-A, Wilt Pruf, Folicote, and Vapor Gard in white spruce; Wilt Pruf and Folicote in western hemlock; and XEF-4-3561-A, Vapor Gard, and Wilt Pruf in Douglas-fir (Table 2).

Water potential measurements made on the seedlings grown for the 7-day RGC test (Table 3) suggest that XEF-43561-A, Wilt Pruf, Folicote, and Vapor Gard were effective in significantly increasing pre-dawn plant water potential in lodgepole pine, white spruce, western hemlock, and Douglasfir seedlings grown under favourable temperature, light, and moisture conditions. Seedlings sprayed with Plantgard and Clear Spray did not have higher pre-dawn water potential levels than untreated seedlings. This suggests that Plantgard and Clear Spray had no effect on transpiration and are thus likely to be less effective in controlling water loss by seedlings 
of the four conifers tested.

In the moisture stress avoidance test, white spruce seedlings treated with XEF-4-3561-A maintained significantly $(p<0.05)$ higher water potential levels than untreated seedlings for 9 days of drought (Figure 1). Wilt Pruf and Vapor Gard treated seedlings had significantly higher water potential levels than untreated seedlings for 5 days (Figure 1). Folicote, Plantgard, and Clear Spray were ineffective in promoting moisture stress avoidance of white spruce seedlings.

In the irrigated, but unfertilized, nursery planting of western hemlock and Douglas-fir, survival was high and unaffected by treatment (Table 4). Growth of western hemlock and Douglasfir was significantly reduced by XEF-4-3561-A, Wilt Pruf, and Vapor Gard. Douglas-fir seedlings treated with Plantgard and Clear Spray had significantly greater growth than the untreated control: 16 and $22 \mathrm{~mm}$ more growth, respectively. The reason for the observed growth promotion is not clear; however, it is unlikely to be a result of reduced transpiration because Plantgard and Clear Spray were ineffective in increasing plant water potential (Table 3 ).

At the forest planting near Prince George, lodgepole pine seedling survival was unaffected by treatment; however, XEF4-3561-A, Wilt Pruf, and Vapor Gard all decreased survival of white spruce seedlings (Table 4). First season shoot growth was slightly, but significantly, greater in Wilt Pruf treated lodgepole pine seedlings. Growth of white spruce seedlings was slightly, but significantly, reduced by XEF-4-3561-A and Wilt Pruf treatments. Field performance improvements of seedlings receiving antitranspirant treatments may have been greater had the treated seedlings been planted on more drought prone planting sites rather than in the irrigated nursery beds (Douglas-fir and western hemlock) and the moist forest site at which survival was greater than $90 \%$ for both lodgepole pine and white spruce. It is a matter for speculation that

\section{Table 2. Antitranspirant effects on root growth capacity before and after cold storage.}

\begin{tabular}{|c|c|c|c|c|c|c|}
\hline \multirow{2}{*}{$\frac{\text { Species }}{\text { Lodgepole pine }}$} & \multirow{2}{*}{$\begin{array}{l}\text { Antitranspirant } \\
\text { XEF-4-3561-A }\end{array}$} & \multicolumn{4}{|c|}{ Root growth capacity ${ }^{1}$} & \multirow[b]{2}{*}{ Storability $^{3}$} \\
\hline & & \multicolumn{2}{|c|}{ Pre-storage } & \multicolumn{2}{|c|}{ Post-storage $^{2}$} & \\
\hline Lodgepole pine & $\begin{array}{l}\text { XEF-4-3561-A } \\
\text { Wilt Pruf } \\
\text { Plantgard } \\
\text { Folicote } \\
\text { Clear Spray } \\
\text { Vapor Gard } \\
\text { Untreated }\end{array}$ & $\begin{array}{l}4.6 \\
4.6 \\
4.8 \\
3.6 \\
4.8 \\
3.7 \\
4.8\end{array}$ & $\begin{array}{l}a^{4} \\
a \\
a \\
b \\
a \\
b \\
a\end{array}$ & $\begin{array}{l}3.5 \\
3.4 \\
3.8 \\
2.2 \\
3.8 \\
1.9 \\
3.4\end{array}$ & $\begin{array}{l}\mathrm{a} \\
\mathrm{a} \\
\mathrm{a} \\
\mathrm{b} \\
\mathrm{a} \\
\mathrm{b} \\
\mathrm{a}\end{array}$ & $\begin{array}{l}.73 \\
.72 \\
.79 \\
.46 \\
.79 \\
.40 \\
.72\end{array}$ \\
\hline White spruce & $\begin{array}{l}\text { XEF-4-3561-A } \\
\text { Wilt Pruf } \\
\text { Plantgard } \\
\text { Folicote } \\
\text { Clear Spray } \\
\text { Vapor Gard } \\
\text { Untreated }\end{array}$ & $\begin{array}{l}2.5 \\
2.8 \\
3.1 \\
3.3 \\
3.4 \\
3.1 \\
3.1\end{array}$ & 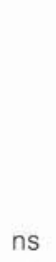 & $\begin{array}{l}1.8 \\
1.9 \\
2.7 \\
2.1 \\
3.2 \\
2.3 \\
2.8\end{array}$ & . & $\begin{array}{r}.56 \\
.60 \\
.86 \\
.68 \\
1.02 \\
.72 \\
.90\end{array}$ \\
\hline Western hemlock & $\begin{array}{l}\text { XEF-4-3561-A } \\
\text { Wilt Pruf } \\
\text { Plantgard } \\
\text { Folicote } \\
\text { Clear Spray } \\
\text { Vapor Gard } \\
\text { Untreated }\end{array}$ & $\begin{array}{l}3.1 \\
3.1 \\
3.8 \\
3.6 \\
3.7 \\
3.8 \\
3.6\end{array}$ & ns & $\begin{array}{l}2.7 \\
2.2 \\
2.8 \\
2.5 \\
3.1 \\
2.9 \\
3.1\end{array}$ & ns & $\begin{array}{l}.76 \\
.62 \\
.79 \\
.70 \\
.88 \\
.81 \\
.88\end{array}$ \\
\hline Douglas-fir & $\begin{array}{l}\text { XEF-4-3561-A } \\
\text { Wilt Pruf } \\
\text { Plantgard } \\
\text { Folicote } \\
\text { Clear Spray } \\
\text { Vapor Gard } \\
\text { Untreated }\end{array}$ & $\begin{array}{l}3.0 \\
3.6 \\
4.1 \\
4.1 \\
3.9 \\
3.6 \\
4.1\end{array}$ & $\begin{array}{l}b \\
a b \\
a \\
a \\
a \\
a b \\
a\end{array}$ & $\begin{array}{l}2.6 \\
3.0 \\
4.0 \\
3.4 \\
4.1 \\
2.8 \\
3.8\end{array}$ & $\begin{array}{l}\mathrm{b} \\
\mathrm{b} \\
\mathrm{a} \\
\mathrm{ab} \\
\mathrm{a} \\
\mathrm{b} \\
\mathrm{a}\end{array}$ & $\begin{array}{l}.62 \\
.73 \\
.97 \\
.83 \\
.98 \\
.67 \\
.92\end{array}$ \\
\hline
\end{tabular}

'Root Growth Capacity assessed using Burdett's (1979) method.

2Storage period was for 12 weeks at $+2^{\circ} \mathrm{C}$.

3Storability $=$ Post-storage RGC of treatment " $x$ "/Pre-storage RGC of Untreated.

${ }^{4}$ Means followed by same letter do not significantly differ at $P \leq 0.05$; ns - not significantly different

Table 3. Predawn ${ }^{1}$ plant water potential (-MPa) of four container-grown conifer species treated with antitranspirants.

\begin{tabular}{|c|c|c|c|c|c|c|c|c|}
\hline \multirow{2}{*}{$\frac{\text { Antitranspirant }}{X E F-4-3561-A}$} & \multicolumn{2}{|c|}{ Lodgepole pine } & \multicolumn{2}{|c|}{ White spruce } & \multicolumn{2}{|c|}{ Western hemlock } & \multicolumn{2}{|c|}{ Douglas-fir } \\
\hline & .45 & $c^{2}$ & .35 & $b$ & .30 & $b$ & .40 & C \\
\hline Wilt Pruf & .50 & bcd & .40 & $b$ & .30 & $b$ & .45 & C \\
\hline Plant Gard & .55 & $a b$ & .60 & a & .35 & $b$ & .85 & a \\
\hline Folicote & .35 & d & .50 & $b$ & .30 & $b$ & .65 & b \\
\hline Clear Spray & .55 & $a b$ & .65 & a & .35 & b & .95 & a \\
\hline Vapor Gard & .40 & $c d$ & .35 & $b$ & .30 & b & .45 & C \\
\hline Untreated & .60 & a & .70 & a & .40 & a & .95 & a \\
\hline
\end{tabular}

'Measurements were made on seedlings after they had been grown for seven days in the pre-storage root growth capacity test conditions.

2Means within a column followed by the same letter do not differ significantly at $P \ll 0.05$. 


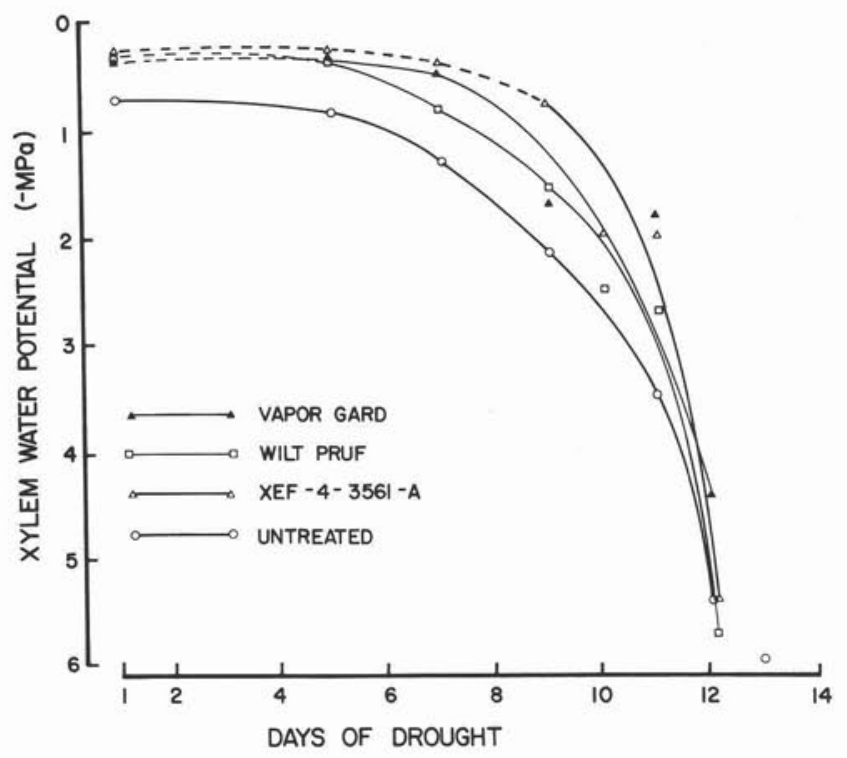

Figure 1. Decrease in plant water potential during a drought period in white spruce seedlings treated with filmforming antitranspirants. That portion of the water potential/days of drought curve for the treated seedlings that is significantly $(p<0.05)$ different from the untreated curve is shown as a broken line. Each point is the mean water potential of four seedlings.

warrants further investigation whether maintenance of higher levels of plant water potential at the expense of reduced $\mathrm{CO}_{2}$ exchange as demonstrated by Davies and Kozlowski (1974, 1975 ) will in fact result in better survival and growth of conifer seedlings.

Time of treatment application was only an important consideration in hemlock seedlings, which grew significantly faster when treated shortly before field planting.

In general, the antitranspirants that effectively increased moisture stress avoidance also had the most negative effects on seedling RGC, storability, and field survival/growth. An important exception to this trend occurred in lodgepole pine seedlings treated with XEF-4-3561-A and Wilt Pruf, where xylem water potential was increased without adversely affecting RGC, storability, or field performance.

\section{Summary}

Of the six antitranspirants tested, Plantgard and Clear Spray had no effect on conifer seedling water relations. A slight growth stimulus, due to unknown causes, was observed when these products were applied to Douglas-fir seedlings. The most effective antitranspirants, in order, were: XEF-4-3561-A, Wilt Pruf, Vapor Gard, and Folicote. These also were generally the most effective compounds in reducing seedling RGC, storability, and field performance.

Antitranspirants should not be considered for operational use on white spruce, western hemlock, or Douglas-fir planting stock at the rates considered in this experiment because of the adverse effects on RGC and field performance.

The possibility of using Wilt Pruf and XEF-4-3561-A on lodgepole pine seedlings should be explored further in operational trials because these two products appear to reduce moisture stress development (Table 3 ) without significantly reducing $R G C$ or storability (Table 2 ) and may actually result in first season field growth improvements (Table 4). Application of the antitranspirants may occur at any operationally convenient time possibly before packaging or in the field before planting.
Table 4. Survival and first season growth of container-grown conifer seedlings treated with several antitranspirants before and after cold storage.

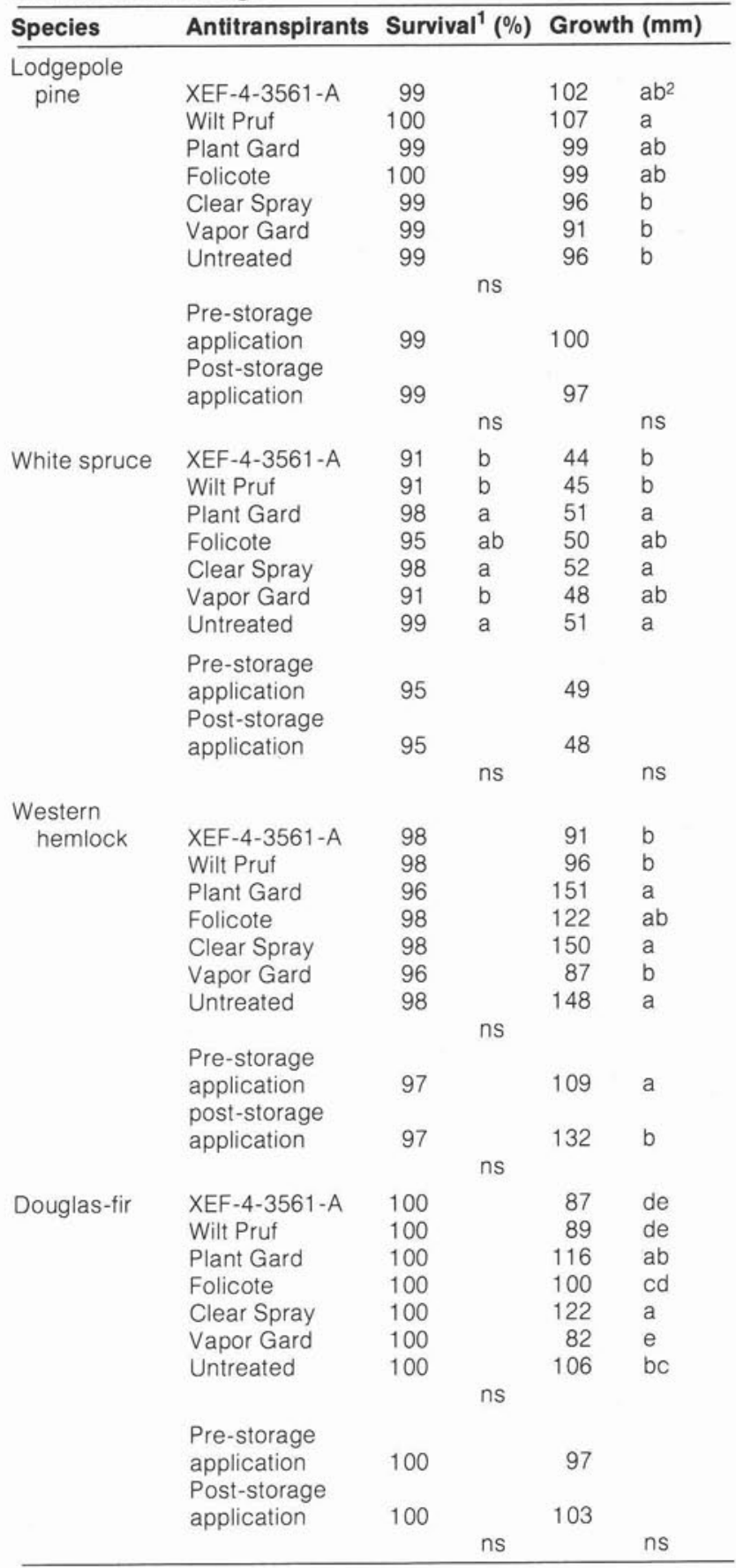

Lodgepole pine and white spruce were outplanted on a forest site near Prince George. BC while Western hemlock and Douglas fir were outplanted in the transplant beds of Surrey Nursery near Vancouver, BC.

2Means followed by same letter do not significantly differ at $p \ll 0.05$

\section{Acknowledgments}

Mr. K. Odlum, formerly of the BC Ministry of Forests, Research Branch, North Road Laboratory, provided most of the technical assistance for this experiment. Assistance in establishing and measuring field plots near Prince George, B.C. was provided by Mr. H. Coates of the Prince George Forest Region research staff. Statistical and programming assistance was received from Ms. W. Bergerud of the BC Ministry of Forests, Research Branch, Victoria, B.C. 


\section{References}

Albrigo, L.G. 1977. Comparison of some antitranspirants on orange trees and fruit. J. Amer. Soc. Hort. Sci. 102: 270-273.

Anderson, J.E. and F. Kreith. 1978. Effects of filmforming and silicone and antitranspirants on four herbaceous plant species. Plant and Soil 49: 161-173.

Burdett, A.N. 1979. New methods for measuring root growth capacity: their value in assessing lodgepole pine stock quality. Can. J. For. Res. 9: 63-67.

Davies, W.J. and T.T. Kozlowski. 1974. Short- and long-term effects of antitranspirants on water relations and photosynthesis of woody plants. J. Amer. Soc. Hort. Sci. 99: 297-304.

Davies, W.J. and T.T. Kozlowski. 1975. Effects of applied abscisic acid and silicone on water relations and photosynthesis of woody plants. Can. J. For. Res. 5: 90-96.

McDaniel, G.L. and G.L. Bresenham. 1978. Use of antitranspirants to improve water relations of Cineraria. Hort Science 13:466467.

Martin, J.D. and C.B. Link. 1978. The potential use of antitranspirants in the greenhouse production of chrysanthemum. J. Amer. Soc. Hort. Sci. 103: 327-331.

Waring, R.H. and B.C. Cleary. 1967. Plant moisture stress: evaluation by pressure bomb. Science 155: 1248-1254.

Weller, S.C. and D.C. Ferree. 1978. Effect of a pinolene-base antitranspirant on fruit growth, net photosynthesis, transpiration, and shoot growth of 'Golden delicious' apple trees. J. Amer. Soc. Hort. Sci. 103: 17-19.

Zar, J.H. 1974. Biostatistical Analysis. Prentice Hall. 620 p.

Woodlot Service (1978) Ltd.

"All Matters Pertalning to Forestry"

GORDON B. YOUNG, B.Sc.F., M.F. Registered Professional Forester 